\title{
Interval Quantity Data Type
}

National Cancer Institute

\section{Source}

National Cancer Institute. Interval Quantity Data Type. NCI Thesaurus. Code C102860.

A data type comprised of a set of consecutive values of an ordered base, which is an abstract generalization for all value data types that have an order relationship. 